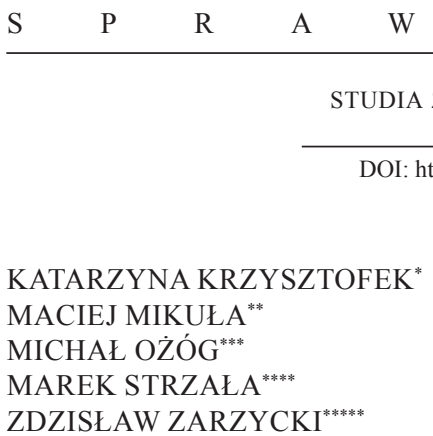

\title{
UROCZYSTOŚĆ WRĘCZENIA MEDALU MERENTIBUS PROF. DR. HAB. WACŁAWOWI URUSZCZAKOWI, KRAKÓW, 15 STYCZNIA 2018 R. ${ }^{1}$
}

W dniu 15 stycznia 2018 r. społeczność Uniwersytetu Jagiellońskiego uhonorowała Profesora dr. hab. Wacława Uruszczaka Medalem Merentibus $^{2}$. Uroczystość wręczenia medalu odbyła się podczas specjalnego posie-

* Dr, Zakład Prawa Kościelnego i Wyznaniowego, Wydział Prawa i Administracji, Uniwersytet Jagielloński, ul. Gołębia 9, 31-007 Kraków, e-mail: k.krzysztofek@uj.edu.pl. ORCID 0000-0003-2579-1454

** Dr hab., Zakład Prawa Kościelnego i Wyznaniowego, Wydział Prawa i Administracji, Uniwersytet Jagielloński, ul. Gołębia 9, 31-007 Kraków, e-mail: maciej.mikula@uj.edu.pl. ORCID 0000-0001-6708-004X.

${ }^{* * *}$ Mgr, doktorant w Zakładzie Prawa Kościelnego i Wyznaniowego, Wydział Prawa i Administracji, Uniwersytet Jagielloński, ul. Gołębia 9, 31-007 Kraków; student Wydziału Prawa Kanonicznego UPJP2; e-mail: michal.ozog@doctoral.uj.edu.pl. ORCID 0000-00024315-5235

**** Dr, Zakład Prawa Kościelnego i Wyznaniowego, Wydział Prawa i Administracji, Uniwersytet Jagielloński, ul. Gołębia 9, 31-007 Kraków, e-mail: strzalamarek@gmail.com. ORCID 0000-0003-1341-3464.

***** Dr hab., Kierownik Zakładu Prawa Kościelnego i Wyznaniowego, Wydział Prawa i Administracji, Uniwersytet Jagielloński, ul. Gołębia 9, 31-007 Kraków, e-mail: zdzislaw. zarzycki@uj.edu.pl. ORCID 0000-0002-4013-886X.

1 Niniejsze sprawozdanie zostało skierowane do druku m.in. w: „Studia z Dziejów Państwa i Prawa Polskiego”, „Przegląd Prawa Wyznaniowego”, „Studia z Prawa Wyznaniowego”, „Krakowskie Studia z Historii Państwa i Prawa” i „Czasopismo Prawno-Historyczne”.

2 Z oficjalnych stron internetowych Uniwersytetu Jagiellońskiego - http://www. uj.edu.pl/uniwersytet-z-collegium-medicum/nagrody-i-wyroznienia/medal-merentibus [dostęp: 15.01.2018] dowiadujemy się, że „Medal Merentibus przyznaje się z tytułu szczegól- 
dzenia Senatu UJ w Auli Collegium Maius Uniwersytetu Jagiellońskiego w Krakowie przy ul. Jagiellońskiej 15 o godz. 11.00. Uroczystości przewodniczył Jego Magnificencja Rektor UJ prof. dr hab. med. Wojciech Nowak - gospodarz miejsca uroczystości. Przywitał on Jubilata (który przybył w mundurze przysługującym komandorowi-rycerzowi papieskiego orderu Św. Sylwestra), Jego małżonkę Barbarę i rodzinę Pana Profesora, członków Senatu UJ, Kwestora UJ oraz władze Wydziału Prawa i Administracji UJ na czele z jego Dziekanem prof. dr. hab. Jerzym Pisulińskim oraz innych przybyłych gości. Wśród nich znaleźli się przedstawiciele ośrodków naukowych w kraju (m.in.: prof. dr hab. Andrzej Białas - prezes PAU w Krakowie; prof. dr hab. Jerzy Malec - Rektor Krakowskiej Akademii im. Andrzeja Frycza Modrzewskiego w Krakowie; ks. infułat dr Bronisław Fidelus; prof. dr hab. Franciszek Ziejka - były rektor UJ; ks. prof. dr hab. Tomasz Rozkrut - dziekan Wydziału Prawa Kanonicznego Uniwersytetu Papieskiego im. Jana Pawła II w Krakowie; ks. prof. dr hab. Piotr Stanisz - b. dziekan Wydziału Prawa, Prawa Kanonicznego i Administracji Katolickiego Uniwersytetu Lubelskiego; prof. dr hab. Józef Ciągwa i prof. dr hab. Marian Mikołajczyk - obydwaj z Uniwersytetu Śląskiego w Katowicach) oraz z różnych instytucji państwowych, towarzystw naukowych i przyjaciele Jubilata.

JM Rektor Wojciech Nowak wprowadzając w uroczystość powiedział m.in.: że studenci, doktoranci, absolwenci oraz pracownicy naukowi Uniwersytetu Jagiellońskiego osiągają w życiu różne sukcesy zawodowe, a osiągnięcia Pana Profesora Wacława Uruszczaka wśród tych osób są wyjątkowe. Podkreślił, że UJ prowadzi od lat konsekwentną politykę nieprzyznawania własnym studentom, doktorantom, absolwentom i profesorom tytułu doktoratu honorowego (doctor honoris causa), zatem jednym ze sposobów nagradzania własnych pracowników naukowych za wybitne zasługi na rzecz Uniwersytetu jest honorowanie ich Medalem Merentibus.

nych zasług dla UJ. Medal może być przyznany osobie, organizacji lub instytucji zarówno z kraju, jak i z zagranicy. Wyjątkowo Medal Merentibus można przyznać również pracownikowi UJ. Decyzję w sprawie przyznania medalu podejmuje (na wniosek Rektora) Senat UJ w drodze uchwały. W razie przyznania medalu dokonuje się odpowiedniego wpisu do Księgi Odznaczonych z uzasadnieniem podjętej decyzji. Wręczenia medalu dokonuje Rektor w czasie uroczystości akademickich. Wraz z medalem wręcza się wyróżnionemu dyplom oraz uroczyście odczytuje treść wpisu do Księgi Odznaczonych”. 
Rektor UJ na wniosek Konwentu Godności Honorowych UJ wyjątkowo może przyznać takie najwyższe wyróżnienie wychowankowi Uniwersytetu Jagiellońskiego za wyjątkowe osiągnięcia organizacyjne, dydaktyczne a przede wszystkim naukowe. JM Rektor z satysfakcją poinformował, że Senat UJ na swoim posiedzeniu w dniu 31 maja 2017 r., uwzględniając wniosek profesorów z Wydziału Prawa i Administracji UJ i po zasięgnięciu opinii Konwentu Godności Honorowych UJ podjął uchwałę o szczególnym uhonorowaniu Pana profesora dr. hab. Wacława Uruszczaka, w szczególności za: znakomite osiągnięcia w pracy badawczej w zakresie dziejów prawa polskiego, historii nauki prawa kościelnego, rozwoju prawa wyznaniowego, jak i edytorstwa źródeł dawnego prawa polskiego, zaangażowanie w kształcenie kolejnych pokoleń polskich prawników oraz dbałość o rozwój kadry naukowej, za zaangażowanie w prace organizacyjne na rzecz Alma Mater w tym za pełnienie funkcji prodziekana Wydziału Prawa i Administracji, kierowanie przez długie lata Katedrą Historii Prawa Polskiego i Zakładem Prawa Kościelnego i Wyznaniowego, za zasługi na rzecz rozwoju bazy materialnej Uniwersytetu poprzez wkład w budowę Centrum Chorób Immunologicznych i Środowiskowych Collegium $\mathrm{Me}$ dicum Uniwersytetu Jagiellońskiego przy ul. Skawińskiej 8 w Krakowie. JM Rektor stwierdził przy tym, że ,majowa decyzja Senatu UJ pozwala nam na przeprowadzenie dzisiejszej uroczystości tym bardziej, że większość z obecnych tutaj osób zna drogę życiową i naukową Profesora Wacława Uruszczaka".

Następnie JM Rektor poprosił Panią prof. dr hab. Dorotę Malec - Prorektor UJ ds. Rozwoju o wygłoszenie zwyczajowej laudacji na cześć Uhonorowanego. Oto jej treść:

„Magnificencjo, Wysoki Senacie, Szanowny Panie Profesorze, Szanowni Państwo,

Przypadł mi zaszczyt wygłoszenia laudacji podczas uroczystości uhonorowania Medalem Merentibus Pana Profesora Wacława Uruszczaka, należącego do grona najwybitniejszych polskich i europejskich uczonych, historyków państwa i prawa, człowieka wielce zasłużonego dla Uniwersytetu Jagiellońskiego.

Podobno w przemówieniu pierwsze zdanie jest najtrudniejsze, a więc mam je już za sobą. Ale czuję, że i następne będa trudne: trzecie, szóste, dziesiąte aż do ostatniego - powiedziała po odebraniu Nagrody Nobla Wi- 
sława Szymborska. Przygotowując się do dzisiejszego wystąpienia przypomniałam sobie te słowa z pełną świadomością jak trudno jest przedstawić postać o tak bogatym dorobku, by nie pominąć spraw ważnych i by nie umknęło to co najważniejsze: człowiek, osoba, dla nas - nauczyciel, mistrz i przyjaciel, dla najbliższych - mąż, ojciec i dziadek.

Prof. dr hab. Wacław Uruszczak urodził się w 1946 r. w Krakowie, w rodzinie znanych brązowników-złotników, zasłużonych dla miasta i jego uniwersytetu. Ojciec Profesora, Marian Uruszczak, był. m.in. twórcą kopii berła rektorskiego z początków XV w.

Z Krakowem i Uniwersytetem Jagiellońskim związane było całe życie Pana Profesora Uruszczaka: po ukończeniu III Liceum Ogólnokształcącego rozpoczął w 1964 r. studia prawnicze na Wydziale Prawa i Administracji UJ, gdzie zdobywał i poszerzał swą wiedzę uczestnicząc w seminariach z historii prawa i ustroju u profesora Adama Vetulaniego, a także z prawa cywilnego u Jana Gwiazdomorskiego i Jana Góreckiego.

Zainteresowania naukowe i temperament badawczy skierowały go jednak wyraźnie już podczas studiów w stronę zagadnień historyczno-prawnych, na co wywarł wpływ Jego wielki mistrz naukowy, profesor Adam Vetulani, uważający Wacława Uruszczaka za swego ostatniego ucznia. Jeszcze jako student przyszły Profesor opublikował pierwsze prace naukowe, obchodziliśmy niedawno 50-lecie jego pracy naukowej. Wkrótce powstawać zaczęły kolejne opracowania, a ich liczba obecnie zbliża się do 500. Wśród nich znalazło się wiele dzieł, które weszły na trwałe do kanonu nauk historyczno-prawnych, wpływając na rozwój nauki w skali polskiej i międzynarodowej.

Szerokie zainteresowania naukowe Profesora obejmują dzieje parlamentaryzmu, dzieje kodyfikacji i prawa w dawnej Polsce, dzieje europejskiej kultury prawnej, prawo kanoniczne, współczesne prawo wyznaniowe. Profesor Wacław Uruszczak jest także zasłużonym edytorem źródeł prawa, w tym wyjątkowo cennej serii wydawniczej konstytucji sejmowych oraz ksiąg sądowych, autorem wielu opracowań o charakterze popularnonaukowym i popularnym, tłumaczem literatury pięknej. Doskonały warsztat naukowy, szerokie zainteresowania i nowatorstwo cechują wszystkie jego prace, za przykład niech posłuży osiągnięcie ostatnie: przesunięcie w istotny sposób chronologii dziejów sejmu polskiego i jedna z pierwszych prac, z 1972 r. O zastosowaniu komputerów w dekretystyce, uznająca znaczenie 
nowoczesnych technologii w pracy naukowej na długo przed pojawieniem się komputerów osobistych oraz Internetu.

Publikuje w renomowanych wydawnictwach polskich i zagranicznych, wnosząc istotny wkład do promowania osiągnięć Uniwersytetu Jagiellońskiego i nauki polskiej, do rozwoju nauki w Europie i świecie. Wyrazem uznania jego pozycji są liczne cytowania w światowej literaturze naukowej i podręcznikach, członkostwo w wielu renomowanych międzynarodowych towarzystwach naukowych oraz wielokrotne nagrody ministra nauki i szkolnictwa wyższego oraz rektora UJ, w tym Laur Jagielloński. Jest także komandorem papieskiego orderu Św. Sylwestra, najwyższego odznaczenia papieskiego przyznawanego osobom świeckim oraz m.in. współzałożycielem stowarzyszenia prawników Ars Legis im. św. Iwo Helory - patrona prawników (2004), organizacji pożytku publicznego, świadczącej nieodpłatną pomoc prawną potrzebującym.

Świetny wykładowca i wychowawca wielu pokoleń prawników, promotor licznych magistrów, doktorów, wykładał z powodzeniem na wielu europejskich uniwersytetach, m.in. Montpellier, Bordeaux, Limognes i Poitiers. Zajmuje od lat szczególną pozycję w nauce europejskiej dzięki cennym inicjatywom w zakresie organizacji życia naukowego, w którym tak aktywnie uczestniczy. Odbywał liczne staże naukowe, m.in. w Instytucie Maxa Plancka we Frankfurcie nad Menem i w Uniwersytecie w Antwerpii, był profesorem wizytującym uniwersytetów w Montpellier I, Limoges, Bordeaux I, Poitiers, utrzymywał (i nadal utrzymuje) kontakty naukowe z uniwersytetami w Liege, Leyden, Lovain, Perugii, Berkeley. Jest redaktorem naczelnym elitarnego, bardzo wysoko ocenianego i cytowanego czasopisma historyczno-prawnego „Krakowskie Studia z Historii Państwa i Prawa”.

Kilka dat dokumentujących przebieg kariery: 1964-1969 studia prawnicze, wkrótce potem aplikacja sądowa, 1975 doktorat, 1981 habilitacja, 1990 tytuł profesora, kilkunastoletnie wykonywanie zawodu adwokata. Rozwojowi naukowemu towarzyszyła bardzo aktywna działalność dla macierzystego Wydziału Prawa i całego Uniwersytetu.

W latach 1985-1986 pełnił obowiązki Dyrektora Instytutu Historyczno-Prawnego Uniwersytetu Jagiellońskiego, a w latach 1988-1991 był zastępcą Dyrektora tego Instytutu. W latach 1990-1994 pełnił funkcję Prodziekana ds. ogólnych Wydziału Prawa i Administracji UJ. Wieloletni Kierownik Katedry Historii Prawa Polskiego oraz Zakładu Prawa Kościel- 
nego i Wyznaniowego. Na przestrzeni lat zasiadał i aktywnie uczestniczył w pracach większości rektorskich i senackich komisji.

Prof. dr hab. Wacław Uruszczak położył także ogromne zasługi dla rozwoju bazy materialnej UJ poprzez udział w pozyskaniu przez Collegium Medicum UJ środków finansowych przyznanych przez rząd Flandrii w latach 1993-1998 na budowę i wyposażenie Centrum Badawczego Chorób Środowiskowych i Immunologicznych II Katedry Chorób Wewnętrznych Collegium Medicum UJ kierowanej przez prof. Andrzeja Szczeklika.

Program uruchomiony został z inicjatywy prof. Hermana Van Goethema, rektora uniwersytetu w Antwerpii, zainspirowanego przez prof. Wacława Uruszczaka, aby potencjalne środki skierować na potrzeby krakowskiej medycyny. Program realizowany był na podstawie umowy zawartej przez rząd Flandrii i Uniwersytet w Antwerpii, a w Krakowie funkcję koordynatora wykonywał prof. dr hab. Wacław Uruszczak, przez okres 4 lat nadzorując postęp budowy i podejmując decyzje o wydatkowaniu belgijskich środków.

W ramach programu przekazano sumę znacznie przekraczającą wartość 1 miliona dolarów, co umożliwiło budowę laboratorium i modernizację kliniki przy ul. Skawińskiej 8. Tym samym Prof. W. Uruszczak miał duży udział w rozbudowie tej placówki, służącej całemu społeczeństwu. W czasie gdy wykonywał zawód adwokata przyczynił się także do odzyskania Domu Gościnnego UJ przy ul. Floriańskiej.

Niesłabnący entuzjazm badawczy i wielkie zaangażowanie Profesora Wacława Uruszczaka w różne formy działalności na rzecz rozwoju nauki i dla dobra Uniwersytetu przyniosły $\mathrm{Mu}$ w ciągu dotychczasowej, kilkudziesięcioletniej pracy naukowej pozycję niekwestionowanego lidera, a niezłomność charakteru i zasady uczciwości naukowej, których zawsze przestrzegał i które wpajał swym uczniom, rolę autorytetu dla całego środowiska. Dla współpracowników i kolegów z Katedry niezwykle ujmujące było jak mocno Profesor podkreślał i podkreśla wagę i znaczenie w jego życiu rodziny: Żony, dzieci, wnuków.

Historia prawa polskiego, dyscyplina naukowa Profesora Wacława Uruszczaka, jest nauką ukazującą rozwój prawa jako ważnego elementu kultury narodowej. Jej ustalenia mają wielkie znaczenie dla formowania współczesnych postaw wobec prawa. Dzięki pracom Profesora kontynuowane są najlepsze tradycje krakowskiej szkoły historii prawa i ustroju, wielkich poprzedników: Michała Bobrzyńskiego, Stanisława Kutrzeby, 
Adama Vetulaniego. Jak podkreślał niejednokrotnie, w ślad za św. Tomaszem z Akwinu, prawo to rozrządzenie rozumu dla dobra wspólnego, dokonane przez tego, komu została powierzona troska o społeczność. I o tych wartościach przypominał i przypomina w swych pracach i działaniach.

Ad multos annos, Panie Profesorze".

Następnie JM Rektor, dziękując Pani Laudatorce za przypomnienie ważniejszych zasług Pana Profesora na rzecz Uniwersytetu, podkreślił, że w ostatnich latach, a zwłaszcza w 2018 r. szczególnego znaczenia nabiera nauka prawa i jego historii w życiu jednostki i państwa.

Następnie zgodnie z tradycją UJ rektor udzielił głosu dziekanowi Wydziału Prawa i Administracji UJ prof. dr hab. Jerzemu Pisulińskiemu, który odczytał tekst łaciński dyplomu o szczególnych zasługach Profesora W. Uruszczaka na rzecz Uniwersytetu Jagiellońskiego. Następnie JM Rektor wręczył osobiście Uhonorowanemu Medal Merentibus wraz z dyplomem. W dalszej części uroczystości głos zabrał Profesor Wacław Uruszczak:

„Magnificencjo Panie Rektorze, Czcigodni Państwo Prorektorzy, Prześwietny Senacie,

Dostojny Panie Dziekanie, Szanowni Panie i Panowie Profesorowie, Czcigodni Księża, Drodzy Państwo, którzy zechcieliście przybyć na tę dzisiejszą uroczystość.

Moje wystąpienie pragnę rozpocząc od gorących i serdecznych podziękowań dla wszystkich Państwa, których działania sprawiły, że możliwe się stało uzyskanie przeze mnie tego wyjątkowego wyróżnienia, jakim jest uniwersytecki Medal Merentibus. Medal ten przyjmuję z wdzięcznością, radością i wzruszeniem. Dziękuję JM Panu Rektorowi Wojciechowi Nowakowi, Pani Prorektor Dorocie Malec, Prześwietnemu Senatowi Uniwersytetu Jagiellońskiego in gremio i wszystkim jego członkom, Konwentowi Godności Honorowych, Panu Dziekanowi Jerzemu Pisulińskiemu, Radzie Wydziału Prawa i Administracji i jej członkom, kolegom, którzy poparli wniosek.

Tytuł Medalu Merentibus wskazuje, że jest on wręczany za zasługi na rzecz uniwersytetu. Chodzi o szczególne zasługi. Jeśli Państwo uznali, że ja na taki medal zasłużyłem, to z pewnością nie wypada mi zaprzeczać, ani tym bardziej odmawiać przyjęcia tego wyróżnienia. Pośród moich zasług wyeksponowany został mój udział w realizacji projektu rozbudowy kliniki II Katedry Chorób Wewnętrznych im. prof. Andrzeja Szczeklika przy 
ulicy Skawińskiej 8. Istotnie uczestniczyłem czynnie w tym przedsięwzięciu przez niemal sześć lat, jako pełnomocnik flamandzkiego koordynatora prof. Hermana Van Goethema, który z ramienia rządu Flandrii administrował przyznanymi funduszami. Było to w latach 1994-1998. Jak do tego doszło, to oczywiście zasługiwałoby na dłuższą opowieść. Udział w tym miała także moja małżonka, która ongiś podpowiedziała mi, aby podsunąć prof. Van Goethemowi ideę wsparcia właśnie krakowskiej medycyny, gdyż w tamtym czasie jej niedofinansowanie było szczególnie rażące. Niejednokrotnie wraz ze mną uczestniczyła w wizytacjach postępu robót na budowie. Jako pełnomocnik, byłem zarazem mężem zaufania. Każda faktura za wykonane prace, przed jej zapłatą z funduszu flamandzkiego, wymagała mojego podpisu. Do rozliczenia wystarczały same moje raporty, które składałem co miesiąc przez szereg lat. A dlaczego właśnie ja? Pewnie dlatego, że jednak byłem pozytywnie postrzegany przez europejskie środowisko historyczno-prawne, jako obecny na międzynarodowych kongresach Société d'Histoire du Droit, czy Société Jean Bodin pour l'Histoire Comparative $d u$ Droit, w latach siedemdziesiątych i osiemdziesiątych ubiegłego stulecia, gdzie także spotykałem kolegów flamandzkich, przede wszystkim wspomnianego prof. Hermana Van Goethem z Uniwersytetu w Antwerpii czy prof. Laurenta Waelkensa z Katolickiego Uniwersytetu w Leuven. Z obojgiem współpracuję po dziś dzień. Osobiście wierzę, że zaważyła na tym moja postawa praktykującego chrześcijanina katolika. W 1992 r. w czasie stażu w Antwerpii w miejscowym uniwersytecie św. Ignacego codziennie uczestniczyłem we mszy świętej w kaplicy uniwersyteckiej, co nie było tam powszechne. Dla rozbudowy tej Kliniki fundusze flamandzkie były bardzo istotnym zaczynem, który skłaniał władze polskie, w szczególności Ministerstwo Zdrowia, do skutecznego współfinansowania. Powstała dzięki temu wspaniała nowoczesna placówka lecznicza i naukowa służąca nie tylko uniwersytetowi i studentom, ale w ogóle mieszkańcom Krakowa i całej Polski. Przyznam w tym miejscu, że dla mnie, udział w rozbudowie Kliniki II Katedry Chorób Wewnętrznych stanowi niezwykłe dzieło, będące w pewnym zakresie moim osiągnięciem życiowym. Oczywiście nie można nie wspomnieć o zasługach prof. Hermana Van Goethem, koordynatora projektu z ramienia Flandrii.

Ja nie pochodzę z rodziny profesorskiej, lecz rzemieślniczej. W mojej rodzinie byłem pierwszy, który ukończył studia wyższe. W szkołach byłem 
wzorowym uczniem, osiągającym niemal zawsze najwyższe oceny. Mój ojciec Marian Uruszczak, mistrz trzech rzemiosł: brązownictwa, złotnictwa i galwanizatorstwa, mawiał: „Mój zawód nie ma w socjalizmie żadnej przyszłości. Uczysz się bardzo dobrze. Idź więc swoją drogą". Ojciec mój był rzemieślnikiem artystą, podobnie jak jego ojciec, a mój dziadek, Grzegorz, który tuż po zakończeniu I wojny światowej założył na Podgórzu warsztat brązowniczy. W Krakowie jest szereg dzieł, które wyszły spod ręki mojego ojca, Mariana Uruszczaka albo samodzielnych, albo wykonywanych wespół z jego bratem Józefem Andrzejem. Między innymi to mój tato wykonał na zamówienie ongiś Muzeum UJ kopię najstarszego berła rektorskiego - berła królowej Jadwigi. Opisał to w Opuscula Musealia (rocznik 1989) prof. Stanisław Waltoś. Zainteresowanych odsyłam do tej publikacji. Wspominam tutaj mojego ojca, gdyż bardzo wiele mu zawdzięczam, a zwłaszcza wdzięczny jestem za wsparcie, że wybrana przeze mnie droga życiowa, zasadniczo wolna od jakichkolwiek sukcesów finansowych, była jednak właściwą. Przyznam, że w młodości miałem co do tego wątpliwości. $\mathrm{Z}$ domu rodzinnego wyniosłem z pewnością podstawową moją cechę, a mianowicie pracowitość, która była cechą obojga moich rodziców - ojca Mariana i matki Zofii, której także niniejszym z serca dziękuję. Jeśli istotnie mam naukowe sukcesy, to obok talentu, zawdzięczam to w pierwszej kolejności wytężonej pracy.

W rzemiośle umiejętności zawodowe, uczniowie, czy jak ich się często określa - terminatorzy, nabywają przez codzienny kontakt z mistrzem. Ta relacja mistrz - uczeń jest także ważna dla uniwersytetu. Mistrz to nie tylko nauczyciel, ale zarazem wychowawca i opiekun, osoba przekazująca swoim uczniom obok wiedzy, także system wartości i wzory postaw. Ja w uniwersytecie kształciłem się u prawdziwego mistrza - Adama Vetulaniego, ongiś filara uniwersyteckiego środowiska konserwatywno-klerykalnego, jak to określano w pewnych kręgach i służbach. W środowisku tym nikt nie należał do PZPR i ja oczywiście też nie należałem. Pod kierunkiem prof. Vetulaniego pisałem pierwsze moje prace i zdobyłem stopień doktora. Później szedłem już własną drogą. Wierzę, że wiele tego co nauczyłem się od mojego mistrza, przekazałem swoim uczniom. W szczególności starałem się uczyć, że zadaniem nauki jest poszukiwanie prawdy, rozumianej tradycyjnie, po arystotelesowsku, jako adaequatio rei et intellectu czyli zgodności subiektywnego sądu z obiektywną rzeczywistością. Dochodzenie do 
prawdy nie jest możliwe bez wolności nauki, rozumianej jak najszerzej, jako wolność badań i nauczania. Wszelkie ograniczenia są na dłuższą metę przeszkodą w rozwoju nauki i samej ludzkości. W ciągu minionych lat mojej pracy było z tym jednak różnie wskutek narzucanych, w szczególności przed 1989 r. ograniczeń. Co do mnie, prawda jako cel naukowych dociekań przyświecała mi zawsze, we wszystkich podejmowanych przeze mnie tematach, jak zwłaszcza w dziedzinie badań nad ustrojem i prawem dawnej Polski, czy nad rolą Kościoła i prawa kanonicznego w rozwoju prawa i kultury prawnej w Europie.

Moja praca i postawa znalazły uznanie w oczach Kościoła. W listopadzie 2016 r. w Uniwersytecie Papieskim Jana Pawła II, na tamtejszym Wydziale Prawa Kanonicznego, odznaczono mnie krzyżem komandora rycerskiego Orderu św. Sylwestra przyznanym przez papieża Franciszka. $\mathrm{Z}$ orderem tym wiąże się nobilitacja i prawo do noszenia munduru i szpady. W swoim liście skierowanym do zebranych na tej uroczystości osób, ksiądz kardynał Stanisław Dziwisz, ówczesny metropolita krakowski napisał następujące słowa:

Dziękuje [profesorowi Uruszczakowi] za wieloletnia prace naukowa na Uniwersytecie Jagiellońskim i Uniwersytecie Papieskim i [za] twórczy wkład w ukazywanie wspólnych korzeni i wzajemnego przenikania się prawa kościelnego i prawa polskiego - w historii i $w$ czasach dzisiejszych. Przyznam, że nie można by lepiej streścić tego, co udało mi się w ciągu 50 lat pracy naukowej dokonać. Napisałem wiele prac. Począwszy od pierwszej wydrukowanej w 1968 r., a skończywszy na ostatniej wszystkie one mają istotną wartość poznawczą. Wierzę, że będą czytane i służyć będą nauce i kulturze polskiej także po wielu latach, a nawet po dziesiątkach lat.

Dziś Uniwersytet Jagielloński nagradza mnie swoim Medalem Merentibus. Medal ten odbieram z wdzięcznością. Alma Mater Jagiellonica była zawsze moją główną „matką karmicielką”, a ja wychowanym przez nią synem. Każdy przychylny gest matki, każdą pochwałę, syn winien przyjąć $\mathrm{z}$ pokorą i wdzięcznością. Tak też jest w moim przypadku. Pragnę w tym miejscu oświadczyć, choć może zabrzmi to nazbyt patetycznie, że całość czy też całokształt mojej pracy i osiągnięć w nauce, w dydaktyce, w działalności organizacyjnej, społecznej była zawsze podejmowana dla dobra Uniwersytetu Jagiellońskiego. Uniwersytet Jagielloński to wyjątkowa instytucja. To „nauk przemożnych perła”, wspólnota profesorów i studentów 
powołana do rozwijania wiedzy i jej przekazywania kolejnym pokoleniom młodzieży. Na każdym, kto tutaj pracuje spoczywa szczególna odpowiedzialność i obowiązek troski o aktualny stan i rozwój tej uczelni. Spoczywa ona zwłaszcza na profesorach, których król Zygmunt I Stary w 1535 r. obdarzył szlachectwem. Szlachectwo to nie jest przywilejem, lecz w istocie zobowiązaniem do jak najlepszej pracy dla dobra społeczeństwa i kraju. Jeśli Państwa zdaniem, udało mi się choć w części zobowiązanie to wykonać, mogę uważać się za człowieka szczęśliwego i spełnionego. Parafrazując Ewangelię św. Łukasza rozdział 17, powiem: „Sługą nieużytecznym jestem; zrobiłem tylko to, co powinienem wykonać".

Pragnę także gorąco podziękować mojej małżonce Barbarze za 47 lat wspólnego życia w sakramentalnym związku. Da Bóg, dożyjemy Kochana Basiu, jubileuszu złotych godów. Dziękuję też bardzo moim dzieciom Michałowi, Oli i nieodżałowanemu świętej pamięci Adamowi. Praca naukowa niekiedy odbywała się kosztem rodziny, przez chroniczny brak czasu wolnego. Przepraszam i dziękuję za ich wyrozumiałość.

Dziękuję też, nie wymieniając żadnych nazwisk, wszystkim moim uczniom, współpracownikom i kolegom, zwłaszcza za niedawny piękny zorganizowany przez nich mój jubileusz 50-lecia pracy naukowej. Życzę, aby ich droga naukowa potoczyła się w pełni udanie. Raz jeszcze dziękuję za to wyróżnienie wszystkim Państwu, a zwłaszcza władzom Uniwersytetu i Wydziału Prawa, a przede wszystkim wspaniałej mojej laudatorce Pani Rektor Dorocie Malec. Uniwersytetowi, Jego Dostojnym Władzom, pracownikom i studentom, życzę wszelkiej pomyślności i wielkich sukcesów w bliższej i dalszej przyszłości.

Na koniec sobie samemu w jesieni życia chciałbym życzyć słowami modlitwy św. Tomasza Morusa, patrona prawników:

Panie, daj mi dobre trawienie i oczywiście coś do trawienia.

Daj zdrowie memu ciału i dobry humor, żeby je utrzymać.

Daj mi zdrowa duszę, Panie,

Abym miat zawsze przed oczyma to, co dobre $i$ czyste, i żebym się nie oburzat w obliczu grzechu,

ale żebym umiat mu zaradzić.

Daj mi ducha, który nie zna nudy,

Pomruków, westchnień ni lamentów,

I nie pozwól, bym traktowat zbyt poważnie 
Tę rzecz w środku, która nazywa się ,ja”.

Daj mi Panie, poczucie humoru.

Spraw, abym umiat śmiać się z dowcipu

Abym umiat wynieść z życia nieco radości

i mógł ją dzielić z innymi. [„Źródło”, nr 24(850) z 15.06.2008 r., s. 13]

Vivat Alma Mater Jagiellonica. Vivat Academia. Vivant Professores. Ad multos annos".

Po wystąpieniu Jubilata, zgodnie z tradycją, chór akademicki „Słowianki" odśpiewał polski hymn państwowy. Następnie JM Rektor UJ zamknął uroczyste posiedzenie Senatu UJ i oficjalną część uroczystości oraz zaprosił wszystkich Gości na poczęstunek do sali sąsiedniej - Stuba Communis, gdzie była możliwość składania Jubilatowi życzeń i gratulacji indywidualnych. Uroczystość wręczenia Profesorowi W. Uruszczakowi Medalu Merentibus spotkała się z żywym zainteresowaniem środowiska naukowego. Dowodem na to są także liczne uroczyste życzenia, telegramy, adresy i maile, które na ręce organizatorów otrzymał Pan Profesor W. Uruszczak, m.in. od: prof. dr hab. Marka Wąsowicza z Instytutu Historii Prawa Uniwersytetu Warszawskiego; ks. prof. dr hab. Henryka Misztala z Katolickiego Uniwersytetu Lubelskiego; prof. dr hab. Sławomira Gawlasa z Instytutu Historycznego Uniwersytetu Warszawskiego; prof. dr hab. Wojciecha Witkowskiego z UMCS w Lublinie; prof. dr hab. Andrzeja Gulczyńskiego z Uniwersytetu Adama Mickiewicza w Poznaniu i Prezesa Poznańskiego Towarzystwa Przyjaciół Nauk; ks. prof. dr hab. Józefa Krzywdy z Uniwersytetu Papieskiego im. Jana Pawła II w Krakowie; prof. dr hab. Adama Lityńskiego z Uniwersytetu Śląskiego w Katowicach; prof. dr hab. Marii Zmierczak z Uniwersytetu Adama Mickiewicza w Poznaniu; od środowiska historyków prawa z Uniwersytetu Mikołaja Kopernika w Toruniu (prof. dr hab. Stanisława Salmonowicza, prof. dr hab. Danuty Janickiej, prof. UMK dr hab. Zbigniewa Naworskiego, prof. UMK dr hab. Andrzeja Gacy), mec. Krystyny Sieniawskiej - Prezes Samorządowego Kolegium Odwoławczego w Krakowie i innych.

Na koniec należy zauważyć, że Profesor dr hab. Wacław Uruszczak jest dopiero trzecim profesorem Wydziału Prawa i Administracji UJ w historii Uniwersytetu Jagiellońskiego, który został uhonorowany Medalem Merentibus. Dotychczas zostali tak odznaczeni jedynie prof. dr hab. Stanisław Waltoś (2001) i prof. dr hab. Stanisław Grodziski (2006). 